\title{
LEIBNIZ OVER RELIGIEUZE PLURIFORMITEIT EN TOLERANTIE
}

\section{F. P.M. JESPERS}

To cite this article: F. P.M. JESPERS (2002) LEIBNIZ OVER RELIGIEUZE PLURIFORMITEIT EN TOLERANTIE, Bijdragen, 63:4, 432-445, DOI: 10.2143/BIJ.63.4.821

To link to this article: https://doi.org/10.2143/BIJ.63.4.821

Published online: 25 Apr 2013.

Submit your article to this journal $\square$

山 Article views: 14

Q View related articles ๘ 


\section{LEIBNIZ OVER RELIGIEUZE PLURIFORMITEIT EN TOLERANTIE}

\section{F.P.M. JESPERS}

Voor de vroeg-moderne visie op religieuze pluriformiteit en tolerantie kan Gottfried Wilhelm Leibniz heel goed als vertegenwoordiger worden opgevoerd. Deze filosoof had een voorliefde voor de beeldspraak van het verlichte denken in een verlichte tijd, die hij met zijn eigen tijd identificeerde. ${ }^{1}$ Alleen vatte hij verlichting eerder op in de zin van rationele kennis over de totale werkelijkheid en van algemene vooruitgang - zoals de Franse Encyclopedisten - en nauwelijks in de door Kant geijkte betekenis van persoonlijke en sociale emancipatie door middel van kritisch denken en autonoom handelen.

Die neiging van Leibniz tot veelweterij, zijn talrijke functies en de uiteenlopende belangen daarbij spelen ons danig parten bij het vaststellen van zijn uiteindelijke ideeën over de veelheid van godsdiensten en de omgang daarmee. Hoe valt de tolerante houding van de diplomaat Leibniz te rijmen met de bekeringsdrift van de lutheraan Leibniz of met de verdediging van de natuurlijke religie door de metafysicus Leibniz? In de ruim dertig dikke banden van zijn nog niet eens voor de helft gepubliceerde nagelaten werken en correspondentie vallen wel erg verschillende meningen en visies aan te treffen. Het reconstrueren van hoofdlijnen en samenhang is een lastige taak.

Een voordeel is echter dat Leibniz vaak aangeeft met wie hij het eens dan wel oneens is. Zodoende zijn zijn meningen vrij exact te situeren binnen de gedachtenontwikkeling van de Verlichting. Zelfs indien zijn ideeën over religieuze pluriformiteit niet geheel consistent zouden blijken, zou dat dan een groot probleem vormen? Zoals bij iedere denker kan er minstens al een ontwikkelingsgang in vermoed worden. En verder: hoe consistent is onze eigen visie op zoiets complex als de vele godsdiensten?

\footnotetext{
1 Vgl. bijv. zijn Mémoire pour les personnes éclairées et de bonne intention, in G.W. Leibniz, Le droit de la raison, textes présentés par $R$. Sève, Parijs 1994, 234-241. F. Jespers, De kracht in alles; het mechanistisch en metafysisch systeem van Leibniz, Assen 1997, 21 e.v., 55 e.v. N. Jolley (ed.), The Cambridge Companion to Leibniz, Cambridge 1995.
} 
Hieronder zal ik eerst stilstaan (1) bij de achtergronden van de Verlichtingsideeën over de godsdienst(en). Vervolgens ga ik in (2) op de concrete stellingname van Leibniz ten opzichte van de verdeelde christelijke kerken en van jodendom, islam en confucianisme. Hierbij komen zijn opvattingen over tolerantie en pluralisme naar voren. Daarna komt de vraag naar de samenhang en de waarheid van de godsdiensten terug in het kader van (3) het pleidooi van Leibniz voor de natuurlijke religie. Bij wijze van conclusie brengen we (4) de hoofdlijnen van bovenstaande ideeën van Leibniz bij elkaar en gaan we na welke bijdrage deze filosoof leverde aan het Verlichtingsdenken over de veelheid van en verhouding tussen de godsdiensten.

\section{Verlichtingsideeën over de godsdiensten}

Het zal niet verbazen dat de tamelijk radicale godsdienstkritiek uit de tweede helft van de achttiende eeuw nog niet bij Leibniz aan te treffen is. Integendeel, Voltaire zet juist hem dan - in de Candide uit 1759 - weg als de naïeve doctor Pangloss die zelfs na de grote aardbeving van Lissabon van vier jaar eerder volhoudt dat wij desondanks op de best mogelijke wereld leven. Maar ook bij een Voltaire vinden we, evenals bij diens tijdgenoten zoals Rousseau, Toland, Lessing en Kant, in de grond een gematigd deïsme. ${ }^{2}$ Het redelijk denken over een Schepper-God blijft gangbaar, maar historische openbaringsmomenten en kerkelijke eigenaardigheden worden betwist. Wat er over blijft is meestal een zuiver rationele 'natuurlijke religie', dat wil zeggen een metafysisch wereldbeeld dat dient als fundament voor een humanitaire ethiek, omgeven met enkele religieuze beelden. De vele concrete godsdiensten en christelijke confessies worden getolereerd als tijdgebonden religieuze expressies hiervan, vooral ten behoeve van het gewone volk.

De diepgaander kritiek van de atheïstische Encyclopedisten of van Hume, bijvoorbeeld in diens Dialogues concerning Natural Religion (in 1779 postuum gepubliceerd), komt bij Leibniz zeker niet voor. Deze late Verlichtingsdenkers concluderen in grote lijnen dat de vele godsdiensten meer kwaad dan goed brengen en dat het beter is alleen de ethische principes ervan als zelfstandige inzichten te handhaven. De politieke machtsuitoefening van de staat dient gescheiden te zijn van de godsdienst. Dat is het begin van een intolerante houding tegenover godsdienst die in de negentiende eeuw langzaam veld wint

${ }^{2}$ Vgl. M. Westphal, 'The emergence of modern philosophy of religion', in P.L. Quinn en C. Taliaferro, A Companion to Philosophy of Religion, Oxford 1997, 111-117. Th. de Boer, De God van de filosofen en de God van Pascal, 's-Gravenhage 1989, vooral hoofdstuk 1. 
in brede lagen van de Europese bevolking en nu nog door velen gedeeld wordt. Leibniz (1646-1716) leefde echter in de vroege Verlichting. Toen moest men nog wennen aan de betrekkelijke rust na de verwoestende godsdienstoorlogen van de zestiende en zeventiende eeuw. In heel Europa keek men met een mengeling van verbazing en afkeer naar de Republiek der Verenigde Nederlanden, waar alle burgers in naam de gereformeerde religie aanhingen, maar waar in feite dopers, katholieken, joden en nog meer gezindten tamelijk ongemoeid werden gelaten. De naar Rotterdam uitgeweken balling John Locke kon er in 1689 ongehinderd zijn Letter concerning Toleration publiceren. Hierin pleit hij voor individuele godsdienstvrijheid en voor een zekere samenwerking van de christelijke kerken ten behoeve van de maatschappelijke opbouw, onder een neutrale staat. Verder verschenen overal steeds meer reisverslagen over beschaafde wilden in Amerika, over de zeer oude en hoog ontwikkelde Chinese en Indische culturen en over de prachtige bouwkunst en literatuur van de Arabische wereld.

In West-Europa ontstond toen een regionale verdeling van christelijke denominaties die nu grotendeels nog bestaat. De religieuze tolerantie en godsdienstvrijheid, aanvankelijk door de politieke en economische situatie afgedwongen, werd geleidelijk aanvaard. Joden hadden een behoorlijke bewegingsvrijheid en zelfs over moslims kon men met een zekere welwillendheid spreken vanaf het moment dat het Turkse gevaar bij Wenen was afgewend - in 1683. Toch bleef godsdienst een lastige factor in de politiek. De keizer in Wenen en de tsaar in Moskou hadden beiden groot belang bij godsdienstvrede, dus bij gezamenlijk optrekken van de verschillende confessies in hun uitgestrekte maar versplinterde rijken. Lodewijk XIV echter en menig andere vorst wakkerden de religieuze controversen liever aan, om zich als 'roi plus chrétien' of anderszins op te kunnen werpen ter verdediging van kerkelijke belangen. In deze warboel van politieke en religieuze verhoudingen heeft Leibniz zich onophoudelijk ingespannen voor samenwerking en vrede.

Michael Walzer wijst er in zijn boek Tolerantie terecht op dat de vroeg-moderne opvatting van tolerantie niet veel verder ging dan gedogen van een eigenlijk ongewenste andere visie of levenswijze. Hij noemt dat het startpunt op een continuum van tolerantie-opvattingen, waarop hij als volgende stadia onderscheidt: onverschillige aanvaarding van de anderen; daarna principieel het recht op andersheid erkennen; vervolgens een esthetische erkenning van veelkleurigheid; tot slot functionele bekrachtiging van de autonomie van anderen vanuit de overtuiging van het voordeel van gedifferentieerde uitwisselingen. ${ }^{3}$ Het is de

${ }^{3}$ M. Walzer, Tolerantie, Baarn 1998, 20. 
moeite waard om na te gaan tot welke positie Leibniz in deze taxonomie gerekend kan worden en wat hij eventueel heeft bijgedragen aan de voortgang van de meningsvorming over tolerantie op het vlak van de godsdiensten.

\section{Leibniz over concrete godsdiensten en atheïsten}

De openbare stellingname van Leibniz over de godsdiensten is tamelijk duidelijk, al is ze zoals gezegd vrij ingewikkeld. ${ }^{4} \mathrm{Hij}$ is een lutheraan die hereniging nastreeft van de christelijke kerken in Europa en uitwisseling met monotheistische godsdiensten buiten Europa. Het grootste gevaar voor godsdienst en samenleving ziet hij in het opkomende atheïsme; dit zal ik verderop uitleggen. Leibniz houdt vast aan zijn lutheraanse overtuiging, maar in de zin van wat we tegenwoordig een oecumenische gezindheid noemen. ${ }^{5}$ Die was ten dele gestoeld op zijn functie als raadsheer van de hertog van Brunswijk te Hannover, dus op Leibniz' diplomatieke taken en zijn juridische benadering van de confessies in het kerkelijk verdeelde Duitsland. Hij had zich grondig verdiept in de theologische standpunten van zijn eigen kerk, van katholieken, calvinisten, oosters orthodoxen en anderen, in de groeiende overtuiging dat de dogmatische controversen rationeel opgelost moesten kunnen worden. In feite acht Leibniz de meest zichtbare verschillen tussen de kerken van ondergeschikte betekenis. Hij benoemt ze vaak als eigenaardigheden in cultus, organisatie en beleving die gerust gehandhaafd mogen blijven. ${ }^{6}$ Maar de geloofsbelijdenis en de leer zijn eigenlijk één, algemeen; daarom gebruikt Leibniz hiervoor meestal - bewust uitdagend - de term 'katholiek'.'

Zijn leven lang zal de Hannoverse raadsheer zich beijveren voor de hereniging der christenen in één universele kerk.

4 Vgl. J. Baruzi, Leibniz et l'organisation religieuse de la terre, Parijs 1907. A.P. Coudert, R.H. Popkin, G.M. Weiner (eds.), Leibniz, Mysticism and Religion, Dordrecht 1998. P. Eisenkopf, Leibniz und die Einigung der Christenheit, München 1975.

${ }^{5}$ U. Goldenbaum, 'Leibniz as a Lutheran', in A.P. Coudert enz. (noot 4), 169-192. G. Utermöhlen, 'Ökumenizität der 'besten Welt', in A. Heinekamp, A. Robinet (Hrsg.), Leibniz: le meilleur des mondes, Stuttgart 1992 (Studia Leibnitiana Sonderheft 21), 65-74. G. Utermöhlen, 'Vereinigung der Konfessionen', in A. Heinekamp, I. Heim (Hrsg.), Leibniz und Europa, Hannover 1994, 95-114.

${ }^{6} \mathrm{Vgl}$. J. le Brun, 'Critique des abus et signifiance des pratiques (la controverse Leibniz-Bossuet)', in Theoria cum praxi: Akten des 3. internationalen Leibniz-Kongreßes, Wiesbaden 1980, 247-257.

7 Vgl. het grote project Demonstrationes Catholicae uit de jaren 1668-1672, waarvoor Leibniz omvangrijke schetsen van de ene 'katholieke' geloofsleer optekende; zie A VI, 1, 489-560. Verder schreef hij onder meer 'katholieke' beschouwingen in de jaren 1680-1686: A VI, 4, 2299-2354 (= G.W. Leibniz, Sämtliche Schriften und Briefe, herausgegeben von der Akademie der Wissenschaften Berlin, Berlin 1923 en later, reeks VI, deel 1 resp. 4). 
"De voorgenomen procedure van de geestelijke godsdienstvrede bestaat hierin, dat men na voorlopig samengaan van beide kanten de onenigheden in bepaalde soorten verdeelt, maar vooral dat men sommige als formuleringskwesties en andere als reëel benoemt, en ook voor elke soort passende middelen voor vrede voorstelt" (A I, 13, 109).

Met dit doel voor ogen heeft Leibniz meerdere malen direct of op de achtergrond deelgenomen aan herenigingsgesprekken tussen de verschillende kerken. Verder presenteerde hij met name in de jaren tussen 1686 en 1692 in briefwisseling met prominente Franse theologen zoals Arnauld, Malebranche en Bossuet zowel concrete plannen voor samenwerking als nauwkeurige formuleringen voor omstreden geloofspunten (met name de transsubstantiatie). ${ }^{8}$ Wat Leibniz voorstelde was een gefaseerde samenwerking van de kerken. ${ }^{9}$ In een eerste fase moesten de wederzijdse veroordelingen worden teruggenomen, de geldigheid van het concilie van Trente worden opgeschort en de overeenkomsten in geloofsleer worden vastgelegd. Onmiddellijk erna konden de kerken als tweede fase in alle landen gaan samenwerken onder leiding van de paus, maar met erkenning van de liturgische en organisatorische eigenheden van de verschillende deelkerken. Ook moesten dan, zoals gezegd, de omstreden geloofspunten nauwkeurig worden omschreven. In een derde fase zou een algemeen concilie al deze controversiële punten moeten oplossen om tot één leer te komen, met de mogelijkheid om meerdere typen van liturgie en bedieningen te behouden. Voor alle drie de fasen heeft Leibniz geregeld concepten uitgewerkt in de overtuiging dat de geloofsleer met behulp van de metafysica en logica tot uniformiteit gebracht moest kunnen worden. Hij kon er zijn correspondenten echter zelden mee overtuigen, omdat die de controversen uiteindelijk meer ecclesiologisch dan dogmatisch wogen. Voor de derde fase van het bijeenroepen van een oecumenisch concilie heeft Leibniz de keizer te Wenen en de tsaar te Moskou benaderd; beiden hadden er immers grote belangen bij, maar slaagden niet in zo'n grootse onderneming vanwege de voorziene politieke consequenties.

Het opmerkelijkste aspect van dit plan is misschien de keuze voor hereniging van alle kerken onder leiding van de paus. Dat stuitte bij protestantse theologen en vorsten natuurlijk op weerstand, maar Leibniz was met name overtuigd

${ }^{8}$ G.W. Leibniz, Die philosophischen Schriften, herausgegeben von C.I. Gerhardt, Berlijn 18751890 (= GP), II, 3-142; I, 317-364; A I, 6-9 passim. Vgl. R.C. Sleigh, Leibniz and Arnauld; A commentary on their correspondence, New Haven 1990. D. Berlioz, 'Les fondements métaphysiques de la concorde religieuse', in Leibniz und Europa; VI. Internationaler Leibniz-Kongreß, Hannover 1995, $35-42$.

9 Vgl. Utermöhlen, 'Vereinigung' (noot 5), 102. 
van het belang van een bekwaam eenhoofdig bestuur, dat dan ook nog eens op goddelijke bijstand kon rekenen. Hiervoor hanteert hij het politieke model van de absolute soeverein, toentertijd geen bijster vooruitstrevend idee. Evenmin kon hij meegaan in de door Locke voorgestelde scheiding van kerk en staat. Leibniz is echter tamelijk revolutionair in de mening dat protestanten en katholieken van elkaar kunnen leren. Zo schreef hij aan een katholieke correspondente het volgende.

"U hebt gelijk als u zegt dat het, bij de manier waarop wij dit opvatten, lijkt alsof de katholieken dadelijk protestant zouden worden en de protestanten katholiek. Dat is ook precies wat wij voorstellen; er zal een mengsel uit voortkomen - als het God behaagt dat alles bevat wat $u$ aan goeds in ons erkent en al wat wij aan goeds in $u$ erkennen" (A I, 9, 187).

In zijn tijd was Leibniz lang niet de enige die zulke godsdienstgesprekken arrangeerde, maar hij ontwikkelde er wel ongeveer de meest vergaande plannen voor. Vandaar dat hij in eigen kring als weinig rechtgelovig werd beschouwd en als sympathisant met de katholieken. De afgeslagen uitnodiging in 1690 om bibliothecaris van het Vaticaan te worden, uiteraard op voorwaarde van bekering tot de roomse kerk, deed aan die naam weinig goed.

Nog in datzelfde jaar knoopte Leibniz een briefwisseling aan met Paul Pellisson, een invloedrijk historicus aan het hof te Versailles, naar aanleiding van diens Réflexions sur les différends de la religion uit $1686 .{ }^{10}$ Pellisson veroordeelde de protestantse kerken en drong aan op terugkeer naar de moederkerk. Leibniz wees hem er beleefd op dat niet zozeer de zuivere leer, maar de vrome instelling van gelovigen doorslaggevend was voor hun verlossing. Vanwege een ware liefde tot God maakt de heilige Geest deze gelovigen tot geestelijk lidmaat van de kerk. ${ }^{11}$ Maar terwille van het zieleheil van de gelovigen zouden de kerken eigenlijk tot een vergelijk moeten komen. Pellisson bleef de ene ware, roomse kerk en haar onfeilbaarheid verdedigen en vond dat zij al dikwijls te tolerant was ten opzichte van de protestanten. Zonder overleg publiceerde hij in 1691 deze brieven, met een commentaar van bovenstaande terughoudende strekking, onder de fraaie maar misleidende titel De la tolérance des religions. Vermoedelijk werd Leibniz bij dit alles vooral gedreven door twee beweegredenen. Ten eerste zag hij de enorme praktische winst van confessionele samenwerking, namelijk minder politieke spanningen (bijvoorbeeld tussen de Duitse staten onderling en ten opzichte van Frankrijk of Rusland) en een gezamenlijk

${ }^{10}$ Zie A I, 6, 75-240; A I, 7, 129-337; A I, 8, 115-221; A I, 9, 61-215.

11 A I, 6, 76-80. 
optreden tegen de Turken. Ten tweede verwachtte hij dat de natuurlijke religie van de Verlichting toch door zou breken en dat kon dan maar het beste vorm krijgen in het verenigde christendom. Op die natuurlijke religie ga ik verderop in.

Leibniz had dus een uitgesproken toekomstverwachting voor de godsdiensten, die ook zijn houding tegenover islam, jodendom en confucianisme bepaalde. Hij voorzag namelijk dat alle volkeren door de internationale contacten en de algemene vooruitgang zouden gaan delen in de Verlichting en dan tot de natuurlijke religie, het liefst in haar christelijke versie, zouden overgaan. Leibniz twijfelde er niet aan dat tot die tijd alle mensen van goede wil verlost zouden worden.

"Men maakt hierbij het bezwaar dat er een oneindig aantal mensen onder de beschaafde volkeren en de barbaren was en nog is dat nooit deze kennis van God en Jezus Christus heeft gehad, waarover men toch moet beschikken om langs de gewone weg verlost te worden. Maar... hierover kan men toch twijfelen, want kunnen wij weten of zij geen gewone of buitengewone hulp krijgen die ons onbekend is?... Zelfs verschillende zeer gezaghebbende theologen in de kerk van Rome hebben geleerd dat een oprechte act van liefde tot God in elk geval voldoet voor het heil, terwijl de genade van Jezus Christus die act versterkt" (Théodicée, par. 95).

Welnu, in jodendom, islam en confucianisme treft men al veel goeds aan zoals een monotheïsme en een bijna christelijke moraal. ${ }^{12}$ In de praktijk wijst Leibniz er voortdurend op dat joden en moslims - waartussen hij overigens weinig verschil in leer ziet - een soort vroege fase van het christendom vertegenwoordigen en daarom respect verdienen. ${ }^{13}$ In principe moeten zij, evenals de Chinezen, bekeerd worden, maar hiervoor is de benadering van de tolerantie en wederzijdse culturele uitwisseling de beste weg. Hij noemt deze drie vormen van monotheïsme compatibel met het christendom. Overigens had Leibniz een grote sympathie voor het jodendom, omdat hij de joodse filosofie en de kabbalistiek uitvoerig bestudeerd had en er ideeën van benutte in zijn monadologie. ${ }^{14}$ Maar op de moslims kon hij scherpe kritiek uitoefenen vanwege hun predestinatieleer, die volgens hem tot fatalisme leidde.

Bij de Chinezen ontwaart Leibniz op basis van directe informatie uit China in het vroegste confucianisme een monotheïsme, dat later onder invloed van

\footnotetext{
12 Vgl. Théodicée, Préface begin, GP VI, 25-27.

13 Vgl. D.J. Cook, 'Leibniz's use and abuse of Judaism and Islam', in M. Dascal en E. Yakira (eds.), Leibniz and Adam, Tel Aviv 1993, 283-297; vgl. GP II, 563.

${ }^{14} \mathrm{Vgl}$. A.P. Coudert, 'Leibniz and the Kabbalah', in Coudert e.a. (noot 4), 47-83.
} 
daoïsme en boeddhisme verloren zou zijn gegaan. Als we de Chinezen naar hun oorspronkelijke godsdienst kunnen laten terugkeren, is dat de kortste weg naar bekering, zo betoogt Leibniz in vele geschriften. ${ }^{15}$ Hiermee kiest hij in de zogenaamde ritenstrijd openlijk de zijde van de door hem bewonderde jezuieten, die in de Chinese missie de lokale termen voor God wilden benutten; dit tegen het Vaticaan en vooraanstaande theologen zoals Malebranche en Bayle, die de Chinezen als materialisten of polytheisten afschilderden.

Leibniz beveelt daarom in eerste instantie erkenning aan van die godsdiensten en uitwisseling van elkaars geloofsleer en praktijken. ${ }^{16}$ In onze tijd zouden we zeggen dat hij de weg van de dialoog aanraadt. Als de gemeenschappelijke geloofspunten erkend zijn, is bekering slechts een kwestie van tijd, meent hij. Wat dat betreft neemt hij een voor die tijd ruim standpunt in.

De niet-monotheisstische godsdiensten echter werden door Leibniz kortweg als heidens afgedaan. Hij zag zowel de christelijke missie als de verbreiding van de zojuist genoemde drie vormen van monotheïsme als de beste manier om dat heidendom in alle continenten op te heffen. ${ }^{17}$ Dus alles bijeen is hij ten opzichte van die andere godsdiensten niet tolerant. Voor een vreedzame verbreiding van de monotheïstische godsdiensten en uitwisseling van christelijke missionarissen met de andere vormen van monotheïsme was volgens hem een grondige kennis van alle godsdiensten en culturen vereist, inclusief beheersing van hun talen, geschiedenis en andere achtergronden. Leibniz zelf schreef onder meer nog in zijn laatste levensjaar een verhandeling over het Chinese godsbegrip, hun wereldbeeld, en hun opvattingen en praktijken betreffende geesten en voorouders. ${ }^{18}$ Bijvoorbeeld aan de jezuiet Bouvet schreef hij op 13 december 1707:

\footnotetext{
"Ik geloof dat het na de verbreiding van het ware geloof bij de Chinezen het verstandigste is om de inzichten en zelfs de voorwerpen van de Chinezen naar ons over te brengen, door ons hun boeken te bezorgen, hun handschriften, granen, dieren, machines, modellen en zelfs door enkele van hun geleerden naar ons te sturen". Twee weken eerder verzekerde hij de pater dat wij de Chinezen veel kunnen leren, "en ook wij op onze beurt kunnen in één keer een wereld van nieuwe ideeën van hen leren, die we anders niet zouden hebben verworven in ik weet niet hoeveel eeuwen". ${ }^{19}$
}

15 G.W. Leibniz, Discours sur la théologie naturelle des Chinois, présentés par Chr. Frémont, Parijs 1987.

16 Vgl. Y.-T. Lai, 'Leibniz and Chinese thougt', in Coudert (noot 4), 136-168.

17 Vgl. R. Widmaier, 'Rosa-Jesuitica, Leibniz' Missionskonzept', in Leibniz und Europa; VI. Internationaler Leibniz-Kongreß, Hannover 1995, 310-320.

${ }^{18}$ Leibniz, Discours (noot 16), 77-144.

19 Ibidem 180 en 176. 
De andere godsdiensten vormden dus geen bedreiging voor het christendom; ze moesten daarentegen worden opgevat als door God gegeven tradities waarvan christenen zelf weer kunnen leren. De rijkdom aan godsdiensten is een extra kans om tot verlicht geloof te kunnen komen. De uitwisseling ermee dient echter niet direct via interreligieuze disputen te verlopen, maar indirect, langs interculturele informatie.

Het grote gevaar voor het christendom was volgens Leibniz gelegen in het opkomende atheïsme. Hij beweerde dat dit voortkwam uit een doorgeschoten vorm van Verlichting. Dit atheïsme was voorbereid door het materialisme van Hobbes en de scheiding tussen uitgebreide en denkende dingen bij Descartes. ${ }^{20}$ Hun navolgers zoals Locke of Spinoza vervielen tot materialisme of naturalisme. $\mathrm{Zij}$ schreven wel over God, maar deze was in hun filosofie eigenlijk overbodig of viel samen met het materiële universum. Dat leidde weer tot een materialistisch mensbeeld, waarvan met name Locke beschuldigd werd in de Nouveaux Essais.

Het kwalijkste gevolg van dit atheïsme was de overtuiging dat alles in de wereld noodzakelijk plaats vindt, zoals Spinoza benadrukte. Dit zou een moreel indifferentisme oproepen, aldus Leibniz, want ethiek was nu overbodig. De mensen zouden vervallen tot fatalisme. Vanwege al deze consequenties diende het atheïsme bestreden te worden, vanaf de aanstichter Descartes tot en met late navolgers zoals Newton.

\footnotetext{
"Als al wat mogelijk is moet gebeuren en als er niets denkbaar is (hoe absurd of onwaardig het ook is) dat niet plaatsvindt op een of andere tijd of plaats in het universum, dan volgt daaruit dat er noch vrije keuze noch een voorzienigheid is, dat datgene wat niet plaatsvindt onmogelijk is, en dat dat wat plaatsvindt noodzakelijk is, precies zoals Hobbes en Spinoza het in de helderste bewoordingen zeggen. Tevens kan men zeggen dat Spinoza slechts enkele kiemplantjes van de filosofie van Descartes verder heeft opgekweekt, zodat ik geloof dat het voor de godsdienst en de vroomheid werkelijk van belang is dat deze filosofie wordt gezuiverd door het verwijderen van de dwalingen die met de waarheid vermengd zijn" (GP II, 563).
}

Tegen dit wijsgerige atheïsme was volgens Leibniz geen theologie opgewassen, alleen de redeneringen van de natuurlijke religie, waarop we nu ingaan.

${ }^{20}$ Vgl. bijv. GP III, 545; IV, 105 e.v.; 281-284; VI, 530-531; A VI, 4, 2344. 


\section{Natuurlijke religie}

De hoogste vorm van godsdienst is in de ogen van Leibniz de natuurlijke religie. ${ }^{21}$ Dit is de algemene religie waartoe ieder mens van nature geneigd is en waarop ieder redelijk mens uitkomt, namelijk de erkenning van een volmaakte SchepperGod en van de onsterfelijkheid van de ziel. Deze rationele godsdienst valt eigenlijk samen met een gezuiverd christendom en zal op den duur de veelheid van godsdiensten overbodig maken. De natuurlijke religie vormt immers het wezen of de waarheid van de vele godsdiensten. De geschiedenis van de mensheid is voldoende ver gevorderd om er uitvoerig over te discussiëren. Leibniz heeft er veel over geschreven en er met name het enige tijdens zijn leven gepubliceerde wijsgerige boek aan gewijd, de Théodicée. ${ }^{22}$ Een zekere aarzeling is af te lezen uit het feit dat de auteur zijn werk aanvankelijk anoniem liet verschijnen in het liberale Amsterdam.

Leibniz presenteert in dit boek de waarheid van de religie als een type van filosofisch christendom. Hij legt vooral de nadruk op de inzichtelijkheid van de wereld, de menselijke vrijheid en de moraal. Zijn beroemde conclusie luidt dat de volmaakte God ons de best mogelijke wereld, le meilleur des mondes, heeft geschonken om in te leven.

"Welnu, deze allerhoogste wijsheid, verbonden met een goedheid die niet minder oneindig is dan zij, kon niet anders dan het beste kiezen.... Men kan evenzo zeggen aangaande de volmaakte wijsheid, die niet minder geordend is dan de wiskunde, dat als er geen beste (optimum) was onder alle mogelijke werelden, God er dan geen zou hebben voortgebracht" (Théodicée par. 8).

Deze wereld, met alle details en precies al deze mensen met hun karakters en hun levenslot zijn door God zó gewild om daarmee de rijkst mogelijke schepping met de eenvoudigste middelen en straks het gelukkigste hemelrijk tot stand te brengen. Deze visie, die het optimistische wereldbeeld van Leibniz wordt genoemd, is zijn metafysische tussenpositie tussen enerzijds de dogmatische theologen en anderzijds de vrijzinnige filosofen van zijn tijd. Rede en geloof stemmen volgens hem dan ook geheel overeen (vgl. het eerste deel van de Théodicée, het Discours préliminaire de la conformité de la foi avec la raison). Enkele trekken van die natuurlijke religie kunnen hier toegelicht worden. God is voor Leibniz het volstrekt redelijke en algoede wezen, maar diens goedheid

${ }^{21}$ Vgl. E. Naert, 'L'idée de religion naturelle selon Leibniz', in G. Bastide e.a., Leibniz, aspects de l'homme et de l'oeuvre, Parijs 1968, 97-104.

${ }^{22} \mathrm{vgl}$. Préface van de Théodicée over natuurlijke religie. 
is gebonden aan de eeuwige waarheden (onder andere de wetten van de logica). Uiteindelijk lijkt God op een soort supercomputer die op basis van voorgegeven wetten en materialen de best mogelijke wereld uitsorteert, schept en in stand houdt. Het verwijt van een onpersoonlijk godsbeeld en deïstisch wereldbeeld ligt voor de hand, maar Leibniz wijst beide steeds verontwaardigd af. Vervolgens zijn vanwege de relatieve volmaaktheid van de wereld wonderen min of meer overbodig of eigenlijk vooraf al verklaarbaar (Théodicée par. 54). Ook al datgene wat op ons als kwaad overkomt, is door God afgewogen en gewild. Het befaamde argument van de theodicee luidt: het kwaad dat ons stoort weegt niet op tegen de totale hoeveelheid goedheid van de gehele schepping (die wij niet kunnen overzien). Of in een metafoor: wij mensen zien alleen mooie of lelijke verfklodders door elkaar, maar overzien niet het complete schilderstuk van de schepping. God stuurt alles aan in een voorbeschikte harmonie, de harmonie préétablie (vgl. Théodicée par. 36-37, 45). Alleen stelt de vrijheid van de mens dan niet veel meer voor. Leibniz erkent inderdaad een zeker determinisme. Het gods- en wereldbeeld van deze natuurlijke religie lijkt op een gesloten systeem waarin alles vastligt, een combinatie van mechanicisme en neoplatonisme. ${ }^{23}$

Leibniz was zich ervan bewust dat zijn positie discutabel was vanuit verschillende benaderingen. Voor theologen deed hij onvoldoende recht aan de grootheid van God en de vrijheid van de mensen. Voor gewone gelovigen bleef er te weinig kerk en ruimte voor religieuze expressies over. Toch erkende Leibniz dat enkele geloofsmysteries in de grond onverklaarbaar waren, zoals de triniteit, de schepping, de incarnatie en de eucharistie (Théodicée, Discours préliminaire, par. 16, 23, 54). Ze vormden een blijvende uitdaging voor de theologie. Maar voor een verlicht gelovige waren echte vroomheid, dus de persoonlijke liefde tot God en de naaste, en enige uitingen ervan voldoende. ${ }^{24}$ De persoonlijke verering van God en de beoefening van de wetenschappen en van de naastenliefde waren belangrijker dan de kerkelijke activiteiten. Met deze visie komt Leibniz dichtbij een moderne, individuele religiositeit.

Het grootste knelpunt was volgens mij gelegen in de onmiskenbare nabijheid van Leibniz' positie aan die van Spinoza. Ofschoon eerstgenoemde deze nabijheid heftig ontkende, is ze er duidelijk. Hoe stelliger Leibniz Spinoza beschuldigt van materialisme en atheïsme, des te verdachter maakt hij zichzelf op dit vlak. Vermoedelijk zijn zowel Leibniz als Spinoza slachtoffer van

\footnotetext{
${ }^{23} \mathrm{Vgl}$. Jespers, a.w., 63.

${ }^{24}$ Théodicée Préface begin (vgl. noot 12).
} 
het toenmalige mechanicisme, waarover ze zo enthousiast waren dat ze het ook toepasten op de geestelijke werkelijkheid. Leibniz corrigeerde dat mechanicisme steeds meer met neoplatoonse elementen, zoals in zijn monadologie. Daardoor krijgt zijn metafysiek het ambivalente karakter van een idealistisch wereldbeeld met mechanistische trekken. ${ }^{25}$ Sluitend is dit wereldbeeld volgens mij niet.

\section{Conclusies}

Drie vragen verdienen in deze nabeschouwing onze aandacht. Eerst moeten we nagaan wat de samenhang in de opstelling van Leibniz tegenover godsdiensten is en of er consistentie zit in zijn uiteenlopende beweringen. Vervolgens kunnen we nagaan hoe deze visie van Leibniz te situeren is in de achtereenvolgende standpunten over pluraliteit en tolerantie in de vroeg-moderne tijd. Tot slot kunnen we enkele verbindingslijnen trekken naar onze tijd.

De opvallendste samenhang tussen de vele teksten van Leibniz aangaande godsdiensten is het evolutieschema dat hem voor ogen staat. Dat schema heeft een metafysisch begin en eindpunt, respectievelijk de schepping en het Rijk Gods, en daartussen een historisch ontwikkelingssysteem dat berust op een combinatie van de eerder genoemde metafysische beginselen (vervat in de natuurlijke religie) en analyses van historische godsdiensten. De algoede God heeft de natuur en de rede aan de mensheid gegeven om er een wereldbeeld uit af te leiden, en ter aanvulling schonk Hij ons de openbaring in het oude Israël en in Christus, zodat de mensheid zich uiteindelijk de natuurlijke religie eigen kan maken. De andere godsdiensten zijn min of meer geslaagde pogingen in de richting van de natuurlijke religie. Ze gaan geleidelijk over van polytheïsme naar monotheïsme, van meerdere monotheïstische systemen naar het christendom, van traditioneel christendom met meerdere kerken naar een aan de natuurlijke religie aangepast christendom. De vele godsdiensten zijn door God gewild en spelen ieder een noodzakelijke rol in dit evolutieschema. Vandaar dat er niet alleen tolerantie nodig is, maar ook studie van en uitwisseling met de hogere niet-christelijke godsdiensten.

De pleidooien van Leibniz voor een universele, pluriforme christelijke kerk in Europa en voor uitwisseling met de andere monotheïstische godsdiensten begeven zich ver voorbij de tolerantie die in de Verlichting was voorgesteld door Locke of Rousseau. In de eerder genoemde taxonomie van Walzer passeert

${ }^{25}$ Vgl. Jespers, a.w., 85-89. 
Leibniz ook het tweede stadium van onverschillige aanvaarding met gemak. Hij verdedigt - derde stadium - het principiële recht op religieuze andersheid, zowel van denominationele pluriformiteit binnen een universele kerk als van meerdere vormen van monotheisme. Maar hij trekt hieruit niet de consequentie die de liberaal Locke wel voorstond: scheiding van kerk en staat. Het vierde stadium van de esthetische erkenning krijgt bij hem vooral het karakter van de fascinatie voor vreemde culturen, met name voor het oude Chinese monotheïsme. Maar uiteindelijk beleeft hij tolerantie op het vijfde niveau, namelijk dat van functionele bekrachtiging van religieuze veelheid en andersheid, vanuit zijn bovengenoemd evolutieschema. Omdat dit een vrijwel gesloten schema is, zoals hierboven bleek, kunnen we bij Leibniz beter van religieuze pluriformiteit dan van pluraliteit spreken. In zijn eigen tijd nam hij hiermee een behoorlijk vooruitstrevend standpunt in.

In de negentiende eeuw zal zijn evolutieschema van de godsdiensten binnen de volkenkunde en de godsdienstwetenschappen algemeen gangbaar en verfijnd worden. We zien het ook terug in Hegels godsdienstfilosofie, in de etnologie van Tylor en Max Müller, of in de cultuurtheorieën van Freud en Weber. Maar de oriëntatie wordt steeds meer pluralistisch. Alleen in de klassieke theologie komt nog de gedachte voor van de ene Christus die in alle godsdiensten en bij alle echte gelovigen werkzaam is, zodat alle godsdiensten zijn voorbestemd om op den duur in het christendom over te gaan. ${ }^{26}$ Dit noemen we de inclusivistische visie op de godsdiensten die ook kenmerkend is voor Leibniz. Binnen dit standpunt verdedigt hij met kracht de interculturele dialoog, vanuit de overtuiging dat Europese christenen evenveel van niet-Europese monotheïsten kunnen leren als dat ze hun aan kennis te bieden hebben. ${ }^{27}$ Ook het christendom zelf, pluriform als het kan zijn, dient voortdurend vernieuwd te worden, enerzijds door die impulsen van buitenaf en anderzijds door discussie met de eigentijdse metafysiek. Het negeren van de eigentijdse - in Leibniz' ogen naar atheïsme neigende - filosofie vormt nog wel de grootste bedreiging voor het christendom. Hiertoe ontwikkelde de Hannoverse raadsheer een omstreden, zo rationeel mogelijke tussenpositie: zijn natuurlijke religie.

Zowel vanwege zijn pleidooi voor een dialoog met de vele godsdiensten vanuit een eigen religieus engagement als vanwege de aanmoediging om actuele

${ }^{26}$ Vgl. bijvoorbeeld Internationale Theologische Commissie, Het christendom en de godsdiensten, Utrecht 1997 (Kerkelijke documentatie nr. 7).

27 Voor de interculturele religieuze dialoog vgl. W. Dupré, Patterns in meaning; Reflections on meaning and truth in cultural reality, religious traditions, and dialogical encounters, Kampen 1994, met name 173-270. 
wijsgerige standpunten serieus te bestuderen op hun religieuze betekenis kan Leibniz een voorbeeld zijn voor onze tijd. Hij zag heel scherp hoe de nieuwe filosofie een verwoording vormde van een materialistisch wereldbeeld (dat we in onze tijd geseculariseerd of zelfs postmodern noemen) en een bijbehorende liberale moraal, waarbij het nog steeds bijzonder lastig is om de waardevolle ideeën ervan te onderscheiden van platte vrijzinnigheid. Het belangrijkste is misschien nog zijn poging om een wijsgerige verantwoording van godsdienst te ontwikkelen; zijn versie van de natuurlijke religie zal velen van ons niet meer overtuigen, maar de onmisbaarheid van een kritische godsdienstfilosofie is er krachtig mee onderstreept.

(Summary: p. 492)

Frans (P.M.) Jespers, geboren 1951, is universitair hoofddocent voor godsdienstwijsbegeerte en godsdienstwetenschap aan de theologische faculteit van de Katholieke Universiteit Nijmegen. Hij publiceert over Leibniz, Habermas, Rorty, interreligieuze dialoog en hedendaagse religiositeit.

Adres: Postbus 9103, 6500 HD Nijmegen. 